\title{
IMPRESSIONS OF LIFE AND LAW ON THE HIGH COURT BENCH
}

\author{
Matthew Palmer*
}

The following is a public lecture given at Victoria University of Wellington on 27 March 2018, organised by the New Zealand Centre for Public Law. In it Justice Matthew Palmer compares his impressions of life and law on the High Court Bench with that in practice and in academia.

\section{INTRODUCTION}

E ngā mana, e ngā waka, e ngā reo. Tēnā koutou, tēnā koutou, tēnā koutou katoa.

Do not tell the Chief Justice but, since my appointment, I have been keeping a diary about my impressions of life and law on the High Court bench - or "judgery" to use a phrase she has used. ${ }^{1}$ I drew on this in giving a lecture entitled "The Judiciary and the Legal Academy" in Hong Kong in December 2016. My starting point was a quote from Richard Posner in his 2016 book on the judiciary and academy, Divergent Paths. ${ }^{2}$ Justice Glazebrook has since considered that book in more depth in relation to the New Zealand Supreme Court. ${ }^{3}$ The quote was: ${ }^{4}$

Judges have had roughly two thousand years of experience in trying, with considerable success, to awe the laity, project a self-congratulatory aura, conceal their failures and inadequacies. As an insider I know how to pull back the curtain, and I think it will actually help the institution for me to do so.

Posner wrote this book after 36 years as a judge of the United States Seventh Circuit Court of Appeals, which followed a full-time career as a law professor at the University of Chicago. My experience is much less fulsome. But I have found comparing my experience of the judiciary and the academy to

* Judge of the High Court of New Zealand. Nothing in this address should be taken to represent the views of the New Zealand judiciary (or academy).

1 Sian Elias, Chief Justice of New Zealand "Judgery and the Rule of Law" (speech at Otago University Faculty of Law, Dunedin, 7 October 2015).

2 Richard A Posner Divergent Paths: The Academy and the Judiciary (Harvard University Press, Cambridge (Mass), 2016).

3 Susan Glazebrook "Academics and the Supreme Court" (2017) 48 VUWLR 237.

4 Posner, above n 2, at x. 
be thought-provoking. Today, I share some of my thoughts with a New Zealand audience, and throw in a few comparisons with the legal profession for good measure. I do so with some apprehension, as my audience today appears primarily to be drawn from the judiciary, academy and profession. I welcome your academic critiques, professional submissions and appellate over-rulings, as I must.

\section{AUCKLAND AND WELLINGTON}

Before I start properly, though, I should note one factor which complicates my observations which are, after all, based on my personal experience of the institutions I examine. My career has jumped around a fair bit: from the public service to academia, to the legal profession in government, then to the bar, and then to the bench. When I jumped from the bar to the bench, I also jumped from Wellington to Auckland. The then-Attorney-General told me I had a choice about that, though I am not sure he and the Chief Justice shared the same view about whose call that was. Despite my 12year-old daughter telling me I had ruined her life forever, I thought being exposed to Auckland would be good for my continuing legal education. I said in my swearing-in I was "not sure that it is now possible to understand New Zealand, and therefore New Zealand law, without understanding Auckland". Now, I am sure: it is not possible. In this respect, at least, Auckland has exceeded my expectations, as it has my daughter's, who now appears happy to have become an Auckland teenager, though not just another Aucklander.

Compared to Wellington, there is less engagement between the bench and profession and the legal academy in Auckland. At neither Auckland law school do you find the numbers or diversity of attendees at a public lecture you do here even in the better weather there. I applaud and encourage the Victoria University of Wellington Law Faculty in continuing to maintain its level and quality of external engagement. We find, at this meeting place, perspectives on and ideas about the law in society that can only benefit from being exposed to other perspectives and ideas. In general, I have found there is less interest in abstract ideas, let alone politics or policy, in Auckland than in Wellington whether on the sidelines of kids' cricket or netball, at dinner parties or even in the academic lecture theatre or the courtroom. There is, however, more interest in business and property (and traffic).

The relative lack of interest in policy amongst counsel in the Auckland courtroom may be related to what I perceive to be the longer tail in the Auckland legal profession than in Wellington. In my view, the Auckland legal profession is more diverse in terms of proficiency as well as ethnicity (and those two variables are not related). It suffers from less coherence, and benefits from that as well. In my experience Auckland counsel rarely talk to each other before a hearing even about how to divide their time, let alone the legal issues at stake. They will likely practise in entirely different villages, called suburbs. They may well not know each other and are, in my view, relatively more prone to argue every point, including points that do not matter (though no lawyer is immune from that temptation). So I think the relative lack of assumed social norms makes litigation less efficient in Auckland than in Wellington. The same aspects also make it less cosy and intimate, which can be a good thing if norms in the legal profession are not healthy. 
My impression is that the nature of the court's case-load is different in Auckland and Wellington. Of my 188 judgments so far, 15 per cent have centred on public law issues. That is higher than I was expecting. I suspect the proportion is higher in Wellington although, interestingly, the statistics suggest there is a similar proportion of judicial reviews. Certainly there is a higher proportion of criminal cases in Auckland. In the year to June 2017, 18 per cent of the new business in the Auckland High Court Registry was made up of criminal trials and appeals compared to 10 per cent in Wellington. I also suspect there are relatively more commercial cases in Auckland. Speaking for myself, 40 per cent of my cases have been criminal, 60 per cent are civil. Twenty-four per cent have centred on commercial, property, trust or common law issues.

I had not realised, before living in Auckland, just how different these two cities are, in their populations, their publics, their cultures. And, of course, this shows up in the business before the courts. Of the four juries I have empanelled in Auckland, only one has had a Pākehā majority. The juries in Hamilton and Rotorua have looked quite different. Of the 188 judgments I have issued so far, 44 per cent of the 263 litigants whose ethnicity I could determine with reasonable confidence have been Pākehā; 14 per cent have been Māori; 10 per cent have been Pasifika; 13 per cent have been Chinese; and 14 per cent have been other Southeast Asian and Indian. I do not have equivalent numbers for Wellington but I suspect they would be different.

And these differences show up in terms of cultural attitudes to law too. I have been struck by how often first-generation Chinese litigants are in court with each other over matters which most Pākehā or Māori usually settle without reaching the courts. Lawyers may contribute to that or perhaps there are cultural factors at play. I do not know. And, as far as I can tell, there appear to be different cultural views of what it means to tell the truth, how binding the law is and whether court orders need to be strictly followed or not. ${ }^{5}$ These are somewhat adventurous impressionistic observations about culture. Auckland and Wellington are not as different from one another as New Zealand is from the United States. But the appreciable differences that do exist make me wonder just what New Zealand culture is and will be, which city's culture is closer to that future culture, and which is the more "provincial". I think the New Zealand legal system, including the profession, the academy and the judiciary, needs to give some conscious thought to the implications of the increasing cultural diversity of New Zealand.

\section{THE JUDICIARY AND ACADEMY}

I turn now to some comparisons between the judiciary and legal academy and the profession. It is difficult to assess whether Posner was less complimentary of the judiciary or the academy in his book. Before enumerating 26 deficiencies of the United States federal judiciary over two chapters, he said: ${ }^{6}$

5 See Zhang $v$ King David Investments Ltd (in liq) [2016] NZHC 3018 (considered on appeal in Young $v$ Zhang [2017] NZCA 622, [2018] NZAR 207; and Ying v Zhang [2018] NZSC 27).

6 Posner, above n 2, at ix-x. 
I had taken too much for granted. I had missed a certain staleness in the current judicial culture - a tendency of judges to recite propositions of doubtful veracity just because they had been repeated before;

a lack of curiosity and imagination; a lack of clarity and candor; and a weak sense of fact.

On the other hand, Posner was also critical of academics. He said "rewards (status, prestige, not necessarily money) in academic law go to doctrinalists and theoreticians who write for each other on a plane of discourse inaccessible or unhelpful to judges".7

America, as Donald Trump seems determined to demonstrate, is different. A number of the tendencies Posner laments in United States scholarship and judgery are absent in New Zealand: the dominant role of judicial clerks; the dominant role of student-edited law reviews; the theoretical bent of much United States legal scholarship; the lack of interaction between the judiciary and academy. And I think Posner's underlying assumption that a key role of the legal academy is to help the judiciary cope with their own systemic difficulties is misplaced though I see at least one former Australian judge, now at a law school, disagrees. ${ }^{8}$

Personally, I would prefer the academy engage in research and scholarship into legal issues that matter to New Zealand's society, polity, economy, and culture and teach law students how to think about those legal issues in context. In New Zealand's legal system today, that requires more focus on Parliament and the executive than on the judiciary. If anything, I think the way law is taught in New Zealand is still too oriented to case law. Of course it is important for students to be taught how to read cases and to appreciate how judges make decisions. But my experience is that New Zealand law graduates understand that at the expense of understanding the relationship between law and policy and how legislation and executive decisions are made in reality.

I do consider milder versions of some of the tendencies Posner identifies in the United States can be detected here. And I think his primary general point applies to New Zealand. I think there is a gulf of understanding and interests between the legal academy and the judiciary in New Zealand and it is growing. More mutual understanding between, and interest in, what each other is and does would be desirable in the separate interests of each.

In what follows I offer "impressions", not of individual academics and judges (tempting though that is), but, first, of who they are and, second, what they do.

\section{WHO ARE ACADEMICS, LAWYERS AND JUDGES?}

I suggest there are more similarities between legal academics, judges and practitioners than differences. Most importantly, they all have law degrees. As any student or graduate of Victoria University of Wellington Law School will know, having a law degree means you can think like a

7 At 295

8 KM Hayne "The Australian Judicial System: Causes for Dissatisfaction" (2018) 92 ALJ 32. 
lawyer - which is not a cultural attribute to be underestimated. I have written in recent articles about the importance of disciplinary training and experience in shaping the different outlook, worldview, culture or language of each branch of government. I have characterised the judiciary as speaking the language of the common law method: ${ }^{9}$

Paradigmatically, common lawyers and judges approach an opinion, an argument or a judgment by identifying the issue, identifying the material facts, outlining the relevant law, examining the arguments from both (ie, two) sides and applying the law to the facts. This is an inductive form of reasoning - from the particulars of individual cases towards the general rule. It pays attention to specific factual context of the particular cases. It looks to past precedents for guidance.

But there are differences in how lawyers, judges and academics speak this language. The working lives of lawyers and judges are dominated by the common law method of examining one case after another. That is the emphasis of a bachelor's degree in law. Graduate degrees, particularly doctorates, tend to take you into other disciplinary realms and into broader perspectives on the normative values that should be in law - into policy.

Every legal academic in New Zealand has a law degree and almost all now have post-graduate law degrees. We have departed from the old English tradition of not requiring law practitioners to have a law degree. We have not yet reached the American position where some academics - including my former doctoral supervisor at Yale - are appointed to law schools without a law degree. But the international market for academics in law, as in other disciplines, increasingly demands academics either have or get a doctorate, mostly, now, from overseas. At Victoria University of Wellington, 20 of the 35 faculty members have doctorates and 15 have master's degrees. The doctorates are from the United States, the United Kingdom, Canada, New Zealand and Germany in that order of frequency.

Accordingly, it is not now uncommon for junior academics to be recruited at or towards the end of their studies - and thus with no or little experience of, or interest in, legal practice. This is a far cry from the days, a generation or two ago, when most faculty members practised law as well. More New Zealand academics do have more experience of the practice of law than in elite United States law schools. A few have had distinguished careers in practice before moving to academia, such as Professor Campbell McLachlan QC. Others, such as Professor John Prebble QC and Professor Richard Boast QC, have developed and maintained expert legal practices in their specialty areas while academics. But, overall, the New Zealand legal academy has less experience of legal practice than it used to and my impression is that is an increasing trend.

With a degree of bootstrap circularity, the broader nature of academic legal inquiry now required in a graduate degree reinforces the broader nature of academic legal inquiry. While cases form a core focus of academic inquiry, academics can and should bring other disciplinary perspectives and

9 Matthew Palmer "Constitutional Dialogue and the Rule of Law" (2017) 47 HKLJ 505 at 518. 
techniques to bear on the legal issues underlying cases. They can and should take a more general perspective of the coherence and consistency of the law found in cases and legislation as well as of policy issues underlying that law.

I suspect some of the disconnect between academia and the judiciary lies in that difference of perspective between law and policy about which I have written elsewhere. ${ }^{10}$ In general, the judiciary must focus on what the law is and academics focus on what the law should be. But, as we know, many judgments make law, particularly at the appellate level. I suggest it is no coincidence that the senior appellate courts, which take broader judicial views of the coherence and consistency of law and the policy underlying it, have the most interest in academic scholarship. And this is reflected in the ratios of post-graduate degrees at the different levels of senior court bench. More judges have post-graduate law degrees than do most practitioners, and the proportion increases through the hierarchy of the courts. Two of the five current Supreme Court judges have doctorates (from Cambridge and Oxford) and two have master's degrees (from Stanford and Queen's). Five of the 10 Court of Appeal judges have master's degrees and another was a Rhodes Scholar. Of the 46 High Court judges and Associate Judges, 17 have master's degrees and four have doctorates.

One of the effects of the different ages and stages of the judicial and academic career paths in New Zealand is that each has a markedly different age profile. I have not got hard statistics on this but my personal experience is a case in point. At $53 \mathrm{I}$ am one of the youngest half dozen or so of the 46 High Court judges. At Victoria University of Wellington, if I were still there, I would be amongst the oldest 10 or so of the 35 academics currently there. Needless to say, different generations have different perspectives of issues, something judges might wish to remember.

The difference in respective career paths also accounts for a difference in how well off judges and academics are financially. Both groups have given up the filthy lure of lucre in private practice, as they will tell you. But judges are paid much better than academics. And because most of them have already spent most of their careers in significantly better paid private practice they are much better off than academics. I have not thought carefully enough about this difference to draw further implications from it. Perhaps the academics here will.

\section{PRESSURE OF WORK}

What of the work of academics, judges and lawyers? Surprisingly, at least to me, I have found being a judge more similar to being an academic than to being a law practitioner. There are two main parts of an academic's job: teaching and research. There are two equivalent parts to a judge's job:

10 Matthew Palmer "Open the Doors and Where are the People? Constitutional Dialogue in the Shadow of the People" in Claire Charters and Dean R Knight (eds) We, The People(s): Participation in Governance (Victoria University Press, Wellington, 2011) at 50. 
hearings and writing judgments. I will spend some time exploring each of these. But first a note about workload.

Academics, judges and lawyers all work hard, as I am sure you will all agree, at least in relation to the group of which you are a member, if you are. But my experience is they all have different views on how hard each other works! This is dangerous territory and you will understand my views are simply impressions based on my personal experience at different stages of my own career. It may not be yours. And there are different dimensions to what "hard work" is: number of hours? or intensity and complexity? or pressure and stress?

My experience is that High Court judges work very hard. I made a list of all the things I dealt with during just one week of being the "duty judge" in Auckland in 2016. The areas of law involved:

- commercial proceedings between a finance company and its debenture trustee;

- custody of children;

- termination of a trust;

- a bail appeal for a burglar;

- $\quad$ setting aside a disposition of property;

- a commercial dispute under arbitration;

- drug dealing criminal charges;

- defamation;

- patent infringement;

- $\quad$ severe commercial relationship difficulties between fruit and vegetable business owners;

- a body corporate arrangement proposal;

- restraining orders over the proceeds of crime;

- confidentiality orders;

- a dispute between neighbours over a driveway;

- a dispute over a caveat preventing sale of a multimillion-dollar property;

- access by the media to a court file regarding copyright infringement;

- $\quad$ taking a guilty plea for grievous bodily harm;

- granting bail, or not, for an alleged murderer;

- granting a bail variation for an alleged kidnapper;

- a bail appeal for assault; and

- a bail appeal for drugs.

Much of the work was procedural management: list court hearing; setting down substantive hearings; making orders about timetabling. But other work was substantive. A duty week in Auckland usually involves three civil list hearings, each of which involves 10 to 30 files being called in an hour or so for procedural directions to be made. It also usually involves:

- $\quad$ an arraignment (where a guilty plea is taken) and/or a sentencing or two;

- $\quad$ several bail or sentence or conviction appeals; and 
- $\quad$ one or two one-hour or two-hour civil hearings into something which may be either very straightforward or quite complex, which often require reserved judgments.

I generally get one duty week each quarter or half year, and one dedicated week a quarter to write judgments. Additional judgment time is also usually allocated after civil hearings and it arises on an ad hoc basis when cases settle or trials resolve. Otherwise, each week is allocated to either civil or criminal hearings, whether short cause hearings of half a day to two days or longer trials of one to 10 weeks. Those hearing weeks include eight to 10 weeks out of town, on circuit, each year. The "circuit" for Auckland judges involves travel to Whangārei, Tauranga, Hamilton and Rotorua.

In two years and five months sitting as a judge I have delivered 188 judgments. That is around three and a half judgments a month, or almost one a week. I have not kept track of the much greater number of minutes and bench notes. These numbers vary over time of course. You cannot issue as many judgments during a long trial. In the course of an 11-week manslaughter and kidnapping jury trial last year, I found I had time to issue only one substantive judgment, two judgments on leave to appeal and two costs judgments that I had previously reserved. During that trial, and relating to the trial I issued five formal rulings, 41 bench notes and five judgments, and three judgments and six minutes immediately prior to it.

There is more than enough work for judges to do in the High Court. But the nature of it is different from that in practice even though you are dealing with court cases in both roles. Again, I should emphasise that these are my views only. I know different judges have different experiences of workload. But, personally, I have felt the pressure of time to be appreciably less at the bench than at the bar. I feel I have the ability to take more time to get my judgments right - or as right as they are going to be. A colleague of mine likens the role to being on a conveyer belt where one case after another inexorably presents itself as an opportunity to trip or fall behind. And too sustained a period of short cause civil hearings can lead to that feeling. But, so far, with the advantage of a big common room in Auckland around which work is spread, I have found it manageable - more manageable than practice and more manageable than life as Dean here.

Incidentally, there is a conventional view of academic life as contemplative, laid-back and relaxed. It is not. The pressures of teaching and research in a New Zealand university today are, in my view, just as great as they often are in practice of law or on the bench. No doubt much pressure in all roles is self-generated by the commitment and dedication of the individual, especially those with an A-type personality. And there are more opportunities, indeed expectations, of attendance at overseas conferences in academia. But those in practice should not assume the pressure of work on an academic who must teach young minds, mark hundreds of assignments or tests, research in depth and write scholarship that contributes original knowledge to the world necessarily reflects the far lower pay rates they receive.

Finally, while I am on such comparisons, I should also say that neither the judiciary, private practice nor academic life contained the level of pressure on time I experienced in the public service, 
either as a policy manager as Deputy Secretary for Justice or as a legal manager as Deputy SolicitorGeneral.

At the bar you feel responsible for the carriage of a client's case. Strangely enough, I have a different sense now of the extent to which counsel contribute to the outcome of a case than I did when I was at the bar. And, perhaps not as strangely, I feel a greater sense of responsibility for that outcome now, as a judge. I do think there is more pressure of responsibility on a judge than an academic or practitioner. While failing students matters, of course, there is nothing equivalent in academic life to the sense of responsibility you have as a judge in sentencing someone to prison. It weighs on you.

I felt a similar pressure of responsibility as a public servant, whether at Crown Law, the Ministry of Justice or the Treasury. But that was responsibility at a different level - responsibility for advice, rather than decisions, usually, as at the bar - and also responsibility for broad effects of policies and the wider interests of the Crown and the public of New Zealand. I feel that as a judge too, especially in making decisions or obiter observations about the law that have precedential significance. But there were only a few occasions as a public servant when I felt the sort of concentrated responsibility for affecting the life of an individual to the extent I do when contemplating sentencing a person to imprisonment for a lengthy period. Although judges are seen as a sort of mouthpiece of society, that is a very personal interaction and it is combined, sometimes, with making precedential decisions with potentially systemic effects.

\section{THE CLASSROOM AND COURTROOM}

When I moved from policy advice and then academia to litigation I thought appearing in court was a bit like a combination of advising a minister and teaching. It had the public performance aspect of teaching targeted at an individual or small group of individual judges. Having now jumped the bench, I have a different view of who is analogous to the lecturer. I have experienced far less performance anxiety on the bench than at the bar during the hearing of a case, rather like the difference between being a lecturer and a student in a class of Socratic dialogue. And, I can confirm my friend David Goddard's suspicion that, while barristers have to enjoy talking, judges have to enjoy listening.

Perhaps presiding in court is like a combination of teaching and chairing a meeting - particularly a faculty meeting. There is still the public performance aspect. In each setting you need a degree of persuasive authority to keep order, and you can find yourself dealing with difficult students, faculty members, counsel or litigants in person. You have to read the materials, think about the issues and be ready to engage with counsel, faculty or students, especially in Socratic teaching. The point of the engagement is different in each role. As a judge the oral hearing is an opportunity to inform yourself about the issues, evidence, law and arguments in order to give the parties a fair hearing and improve the ultimate quality of your judgment, though it may have the effect of helping counsel better understand the case, the nature of advocacy and the law in general. As a lecturer, the lecture is an opportunity to inform the students about the specific and general aspects of the law as well as to teach them to "think like a lawyer". 
I have not yet seen an equivalent to the practice of some lecturers at Victoria walking out of class if enough students randomly called on have not prepared. With some counsel it is tempting, but it would not be fair to their clients. With litigants in person I suspect it might engender a similar reaction to that experienced by one lecturer at Victoria when I was Dean. Within an hour of the lecturer walking out, I received a phone call from The Dominion Post after students complained.

Like some students, a few counsel and most litigants in person are ill-equipped to make legal arguments - usually in inverse proportion to their own confidence. As I said in a recent judgment, in relation to litigants in person there is a fine line to be walked. ${ }^{11}$ And 16 per cent of my cases, usually civil, have involved litigants in person.

I note, for the benefit of Victoria law students here, that Socratic dialogue does teach you how to perform as counsel appearing in court. It has all the same aspects - lack of time to prepare, the terror of not knowing what questions will be asked, the power imbalance, and the huge buzz after an effective interaction. I consider the most effective gentle Socratic dialogue I have conducted to have been not in a classroom but in a criminal sentence appeal in a courtroom in Hamilton, which resulted in Crown consent to turn it into a conviction appeal as well, which was ultimately successful.

\section{JUDGMENTS, SCHOLARSHIP AND OPINIONS}

In my view, the role of judge is not only similar to that of lecturer in terms of court or classroom appearances but also in the other primary aspect of each role. After a hearing or lecture, you wander back to your chambers or office to write. The nature of what you write is different. But in essence, each job involves appearing in public and writing in private. As does that of the barrister.

One of the most significant differences between the writing of legal academics and judges, and between lawyers and judges, is that a judge is required to make decisions. You cannot end your judgment with a plea for other scholars to research and clarify the area of law. You cannot end by reference to one hand and the other. You cannot give a percentage chance of success. You must decide and the reasons for your decision will be public. At the Auckland launch of the Feminist Judgments of Aotearoa book, ${ }^{12}$ Professor Janet Maclean noted that as a point of distinction compared with academic work. I concur. Though there is not nearly as much difference in that between judges and the law officers of the Crown, who often also make authoritative decisions. ${ }^{13}$

Incidentally, I note for judges that what they say in judgments matters in the academy. It provides more fodder for academic discourse. But academics can also take encouragement and stimulation

11 Low Volume Vehicle Technical Assoc Inc v Brett [2017] NZHC 3281.

12 Elisabeth McDonald and others (eds) Feminist Judgments of Aotearoa New Zealand - Te Rino: A Two Stranded-Rope (Hart Publishing, Oxford, 2017).

13 Matthew Palmer "What is New Zealand's constitution and who interprets it? Constitutional realism and the importance of public office-holders" (2006) 17 PLR 133. 
from judgments engaging with their critiques. This demonstrates their work is of value in the real world, if it is. And it may be recognised as a formal indicator of "peer esteem" in the PerformanceBased Research Fund (PBRF) academic assessment and funding system. Personally, I think it is useful for judgments to stimulate agreement and disagreement with good quality and relevant academic commentary, where the judge is aware of it and has time to do so. I try to make a practice of that. In fact, I am happiest when I write a judgment that does three things simultaneously:

- $\quad$ resolves the dispute between the parties;

- develops the law; and

- contributes to academic debates about what the law is and how it should be developed.

There are more opportunities to do this than I had expected.

Judgments are usually shorter than academic articles, and are certainly shorter than books, though many are longer than they need to be. I was struck by the observation of one judge who found writing judgments diametrically different to writing opinions for clients in practice. Instead of writing with a slant or angle orientated to the client, a judgment is written on a neutral basis, in the public interest, based on what the judge thinks the law is and how it applies to the facts. What struck me was not that distinction, but the fact I see almost no difference between the voice in which I write judgments and articles. A judge and an academic both write in their own voices, about what they understand the law to be and what they think it should be. And I have found the academic experience of writing a doctoral dissertation and books - with all the work involved in striving for structure, coherence and clarity to be immensely useful in writing longer judgments. When I say longer, my longest judgment so far is 194 paragraphs - involving the intersection of tort and contract liability in relation to interest rate swaps to dairy farmers. ${ }^{14}$

I have found matters of fact are much harder to decide than matters of law. The facts of a case are served up to you by witnesses and documents. Lawyers draw your attention to the facts they submit are salient. Sometimes their account is not enough for you to be sure of what happened. But you still have to make a decision about them. When in doubt I have found, so far, the best approach is to be very transparent about the limitations of the material before you, what you think about them and why.

The law is much easier. You can retire to your chambers to think about it, unless it is a jury trial, and get your clerk to do more research - though significant additional information should be put to counsel for comment. I have been blessed with exceptionally talented and helpful law clerks: Stephen Laing, for a few months, Yasmin Olsen for two years and now Jessica Storey. Most High Court judges share one clerk between two and have a full associate. I have reversed that ratio as have a few other judges now. I greatly value being able to have a whole clerk and, instead, to share an associate, Bella Panoho, for whose help I am also extremely grateful. I treat a clerk pretty much as I did a research

14 Cygnet Farms Ltd v ANZ Bank New Zealand (No 2) [2016] NZHC 2838, [2017] 2 NZLR 538. 
assistant in law school - seeking research memoranda about aspects of law, issue spotting in upcoming cases, fact checking as well as proofing and also as a sounding board. This is another debt my judging has to academia.

Posner complained bitterly in his book about the United States practice of law clerks doing the first drafts of judgments. I agree. I consider committing my reasoning to writing constitutes my "judgement" and determines the result of a case. To me, reasons and reasoning are the most distinctive aspect of the judicial enterprise compared with that of the other two branches of government. The judiciary is required to reason and to make public that reasoning in applying the law to the facts of individual cases to "do right by law". So I am appointed to reason; my law clerks are not. It seems that is no longer thought to be the case in the United States appellate courts. I do not understand that to be the position in New Zealand and it should not be.

Oral judgments are still delivered in New Zealand. Many judges, including me, deliver oral judgments for bail and sentence appeals and sometimes other matters as well. That accounts for 29 per cent of my judgments so far. But the majority of judgments are reserved and written. I think the mode of delivery matters. There is something about pinning inchoate thoughts down in writing that requires them to be more precisely formulated. I do not like the expression "reduced to writing" for this reason - I prefer "committed to writing". Committing your views to writing commits you to a certain path of logic and reasoning. If you get stuck you can retrace your steps to see where you went wrong. You cannot do that if your steps are already uttered orally.

Furthermore my observation is that the mode by which thoughts are committed to writing matters. Dictating preserves much of the tone and style of orality. I also think it makes for more discursive language and more words. I was taught to touch type at secondary school in the United States, so since the advent of the personal computer in the 1980s I have always written by typing on screen. I think on screen. I hope that makes my writing tighter and clearer than it would be otherwise. But in any case, by now, I cannot do it any other way.

My most important observation about the process of writing judgments is that it matters. My experience is that the need to explain your reasoning is a very real constraint on the discretion of judges. I had always been sceptical about whether judges decide the result and write the reasoning to fit. Early on as a judge, I got into the habit of writing a summary paragraph, or sometimes two, immediately after the hearing. Usually there is a gap of several weeks between a hearing and when you can start writing a judgment - because there is almost always a backlog to deal with. But within a month of starting as a judge, I found my reasoning could change the result I thought I favoured. A fact or an aspect of law not appreciated at the hearing can make its presence felt when I explain my reasoning in writing. And, it can change the result I thought I was going to reach.

I have also adopted the practice of including my summary at the beginning of a written judgment. This is probably influenced by the practice I have always liked of some academic journals of requiring abstracts at the beginning of academic articles they publish, as well as the need to summarise advice 
for ministers. I am in a minority in doing this in judgments in New Zealand - there are only two other High Court judges who routinely put the result upfront. I think the view against it is that it can make the result of the judgment look predetermined. But a judgment is not a mystery novel. Readers of a written judgment know the result has already been determined and usually flick to the end to find out the answer. They want to know what the result is and the reasons for it and encapsulating both of those things upfront in a summary is just that - upfront. If I do not summarise it someone else will. I would rather do it myself, as part of the judgment. I think it improves the accessibility of the judgment, and therefore the law, to the reader and thereby enhances the rule of law. A realist committed to candour could hardly do anything else.

\section{GENERALISM AND SPECIALISM}

I think the second most significant difference between legal academics and judges is that academics are specialists and judges are generalists. Posner makes this point about the United States and it is true in New Zealand too. Academics are now advised to specialise at a relatively early stage of their careers - ideally in areas in which they both teach and research. By the time they become senior academics they have sometimes broadened out again, usually by broadening their areas of speciality. Professor John Burrows QC, a national taonga, is a stand-out example. He has been the primary author of the standard text on statutory interpretation and co-author of texts on contract law, tort law and media law. ${ }^{15}$

Judges in the senior courts must deal with all legal disputes which come their way in whatever area of law. My greatest satisfaction in academic work lay in the opportunity to become more expert in the depths of a particular area of law. My greatest satisfaction in judicial work so far is to gain some understanding of the patterns across broad swathes of law. Doing so promotes consistency and coherence in the application of legal principle across all areas of law. The profession has a choice. But I do consider overspecialisation in some areas of the profession - the tax bar and resource management bar spring to mind - has had negative effects on the understanding of law in those fields.

Generalism must, however, mean that, especially when they are relatively new, judges are dealing with areas of law of which they do not fully appreciate all the ins and outs. In the 16 judgments I delivered in my first three months of being a judge I had previously come across the relevant law in only one. That one, in which I considered I had some expertise, was the only one that was appealed and, of course, overturned both by the Court of Appeal and the Supreme Court. ${ }^{16}$ Though the score

15 For the latest editions of these texts see Ross Carter Burrows and Carter Statute Law in New Zealand (5th ed, LexisNexis, Wellington, 2015); Stephen Todd and others (eds) The Law of Torts in New Zealand (7th ed, Thomson Reuters, Wellington, 2016); Jeremy Finn, Stephen Todd and Matthew Barber Burrows, Finn and Todd on the Law of Contract in New Zealand (6th ed, LexisNexis, Wellington, 2018); and Ursula Cheer Burrows and Cheer Media Law in New Zealand (7th ed, 2015, LexisNexis, Wellington).

16 Royal Forest and Bird Protection Society of New Zealand Inc v Minister of Conservation [2016] NZHC 220, (2016) 19 ELRNZ 370; Royal Forest and Bird Protection Society of New Zealand Inc v Minister of 
was five to four across all three benches! The process of refinement on appeal clearly benefited the nature of the arguments and quality of the ultimate decision.

\section{APPEALS}

The decisions of all judges are subject to appeal, unless you are a Supreme Court judge who is always right (because you are final). My reaction to being appealed is not what I had thought it might be. Before I was appointed, I regarded with some scepticism the claim by judges that they did not much mind being overturned on appeal. One reason why I mind less than I expected is that by the time the appellate judgment is out, you struggle to remember the detail of what you had held or to muster the energy to go back over it. A judge is always aware that any decision could be appealed. You expect some judgments to be appealed - especially in criminal law or in novel areas of law. And if you make a mistake then you want that mistake to be corrected on appeal, particularly when you are dealing with far-reaching decisions on people's personal liberty.

I was interested in my own reactions to the two appeals which have overturned my decisions so far. I have not minded the end result changing in either - I regarded the final appellate decision in each as entirely reasonable. In fact, in one I liked the outcome of the appellate judgment much better than I liked that of my own. However, I have felt minor irritation at a statement in one of the appeal judgments that I felt mis-characterised a minor part of the reasoning in my judgment.

I still think there is usually some effect on the ego of being overturned. The extent may differ from judge to judge. But I think its existence is a reason why there are issues of principle with the commonplace practice in New Zealand of judges deciding whether to grant leave to appeal from their own decisions in certain sorts of cases. There is a safety valve in the Court of Appeal being able to have a second look at such applications. There are good practical reasons of efficiency supporting the practice. And my view is in the minority. But, in terms of the long-term legitimacy of the judiciary, I do not much like the risk that a judge deciding whether there should be an appeal from his or her own judgment would be perceived to be a judge in his or her own cause. A judge's judgment is not his or her own "cause", of course. But I doubt that distinction would be widely appreciated by litigants or lay observers.

Academics do not suffer from appeals - though the PBRF might be regarded as one. For those of you who do not know, the PBRF is an exercise conducted by panels of academics to assess the quality of other academics' research for institutional funding purposes. As you might expect, it was deeply unpopular with most academics when it was introduced. As a dean, and as a member of the first two PBRF panels in law, I consider it had beneficial effects in enhancing the research culture in New Zealand law schools.

Conservation [2016] NZCA 411, [2016] 3 NZLR 828; and Hawke's Bay Regional Investment Co Ltd v Royal Forest and Bird Protection Society of New Zealand Inc [2017] NZSC 106, [2017] 1 NZLR 1041. 
But the system has had unfortunate effects in skewing the perceived value placed on certain types of academic publications:

- There has been a perception that publishing in elite overseas academic publications matters more than in New Zealand publications under the PBRF.

- There has been a perception that texts do not carry as much weight as articles.

- And there has been a perception that, to be a serious legal academic, you must grapple with jurisprudential theory in your publications.

There is something in these perceptions. Publication in the Modern Law Review will be a marker of quality. Revisions to a previous edition of a law text do not always demonstrate significant amounts of original academic scholarship; they may be simple updating. And attending to the theoretical groundings of any field of law will deepen understanding of it. But my experience of the PBRF was the Law Panel members read all of the nominated publications and made their own assessment of their quality - where they were published and whether they were texts or articles mattered less than what they said. Pure legal theory was assessed alongside all other areas of law. Those who compose the law members of the PBRF Panel can do most to assist by ensuring the value attached to legal scholarship does not suffer from such distortions as those perceived, and by communicating accurate signals of what is valued in New Zealand. Because perception can become its own reality.

As a generalist judge I particularly value specialist legal texts that bring order and coherence to fields of case law that are otherwise difficult to access. I value articles on aspects of New Zealand law which are often of less interest to foreign journals than comparative work. And, while I value the role of theory in revealing underlying fault lines in the coherence of law, I do share Posner's concern that the United States legal academy is at risk of disappearing into its own theoretical artifice if it does not stay grounded in its application to legal issues that matter. I do not consider the New Zealand academy has come close to reaching the ethereal heights of some North American scholarship. But academic markets are international and are still often driven by trends in North America. I suggest care has to be taken by legal theorists to ensure theory is (eventually) applied to legal issues that matter.

\section{$X \quad$ INDEPENDENCE}

I make one final observation about a common cultural attitude of the legal academy, judiciary and profession. They are all jealous of their independence, which has legal protection in each case:

- Section 23 of the Constitution Act 1986 protects judges against removal and s 3 of the Senior Courts Act 2016 recognises the established constitutional doctrine of judicial independence. Each New Zealand judge is not only independent of the other branches of government but of each other, except as provided otherwise by law.

- Academics are not legally immune from removal. But s 161 of the Education Act 1989 declares the intention of Parliament in enacting the provisions of the Act relating to institutions that "academic freedom and the autonomy of institutions are to be preserved and enhanced". It defines academic freedom to include "the freedom of academic staff and 
students, within the law, to question and test received wisdom, to put forward new ideas and to state controversial or unpopular opinions". Section 162 further recognises universities' role as "critic and conscience of society".

- Law practitioners, too, enjoy statutory recognition of the independence of their role. Section 4 of the Lawyers and Conveyancers Act 2006 declares the fundamental obligations of lawyers to include the obligations: to uphold the rule of law; to facilitate the administration of justice in New Zealand; and to be independent in providing regulated services in accordance with all fiduciary duties to his or her clients, whose interests he or she has an obligation to protect, subject to overriding duties as an officer of the High Court. Law practitioners in government have an additional level of independence as public servants.

My experience is that all three groups of lawyers, in the judiciary, the academy, and the profession, feel their independence keenly. They will assert it when they consider they need to. That is how it should be but it does have a consequence with which some people here will be familiar.

None of these groups of lawyers or former lawyers much like management or being managed. That may be a cultural attitude of lawyers generally. I share it. The oft-used metaphor of herding cats springs to mind. I have managed three groups of around 40 lawyers - as policy advisers in the Ministry of Justice, as legal academics at Victoria University, and as legal advisers in Crown Law. I am now a member of a group of 46 former lawyers on the High Court. The similarities between all those groups' collective attitudes to management vastly outweigh their differences. It is difficult to tell whether academics or judges are the most resistant. In this regard I draw to Dean Hickford's attention Minerva Cheevy's 2011 blog on Advanced Faculty Wrangling, for an extended analogy of cat herding, if he has not seen it already. ${ }^{17}$ Actually, at a big picture level, I think resistance is often justified and not always futile, though it can manifest in unfortunate ways. The consequence can be significant tensions between faculty members and university management and between judges and the Ministry of Justice. But both of those topics are for a different lecture.

I should say, though, what a supportive environment I have found the Auckland High Court common room to be. It collectively welcomes new arrivals and supports you on an ongoing basis as does what is known as the wider judicial "family".

\section{PUBLIC ENGAGEMENT}

Finally, I want to note one dimension of the academic role which I suggest academics could do better and judges could learn from. Section 162 of the Education Act, which follows the section which preserves academic freedom, itemises five characteristics possessed by all universities. One of them is they "accept a role as critic and conscience of society". This is sometimes cited by academics as

17 Minerva Cheevy "Advanced faculty wrangling techniques" (23 September 2011) The Chronicle $<$ www.chronicle.com>. 
part and parcel of their academic freedom. But I think that it contains positive obligations on them as well.

When I was Dean of Law at Victoria I would often be contacted to comment by the national media on issues of public law. I would try to do so, as long as I felt well enough informed about the matter, because I considered and still consider that is part of the role of universities. Sometimes, if I was too busy or conflicted, I would not comment and on some of those occasions, the story would not run or would quickly die. I think the legal academy in New Zealand do not make their expert views available enough to New Zealand society, whether as critic and conscience or as commentators. There are a number who do and do so well - I think of Dr Dean Knight and Professor Andrew Geddis in particular.

Many legal academics, somewhat surprisingly, shun public exposure and prefer to keep modestly to themselves, teaching and researching and staking out positions only in academic publications. But academic publications are not enough. Participation in mainstream and social media is vital to ensure New Zealand has a robust and informed civil society. That is more important than ever in an international age of post-truth politics, fake news, alternative facts and what seems to be an international trend towards illiberalism even in democracies. New Zealand society needs critics and consciences to speak up. Legal academics have particular authority and expertise to share. Perhaps they could start with taking up some of the topics I have covered impressionistically today, which are not written on extensively, and which lack a rigorous theoretical framework which I have not remedied.

And perhaps judges need to think about whether that is a similarity or a difference with their role. Judges do and must speak authoritatively of the law through their judgments. Only occasionally do New Zealand judges speak extrajudicially. At the time of giving this lecture, no speeches or public lectures by judges are posted on the Courts of New Zealand website for 2018. ${ }^{18}$ Only eight speeches or public lectures are posted from 2017 and 10 in 2016. There were 20 in 2015. Of those 38 speeches in four years, three judges gave all but six of them: Elias CJ, Glazebrook J and Kós J and P (and I gave two of those six).

There is room for more contribution to public discourse by judges. I am not saying judges should publicly advocate policy or political positions. They should not. But greater public understanding and discussion of the judicial role ought to enhance support for the rule of law which is and ought to be a constitutional norm in New Zealand. I believe extrajudicial stimulation can contribute to that. As I have tried to do today.

Nā reira, tēnā koutou, tēnā koutou, tēnā tatou katoa.

18 Courts of New Zealand "Speeches and papers" <www.courtsofnz.govt.nz>. 
